\title{
Applications of Bacteriophages in the Treatment of Localized Infections in Humans
}

\author{
Vera V. Morozova*, Valentin V. Vlassov and Nina V. Tikunova \\ Laboratory of Molecular Microbiology, Institute of Chemical Biology and Fundamental Medicine (RAS), Novosibirsk, Russia
}

In the recent years, multidrug-resistant bacteria have become a global threat, and phage therapy may to be used as an alternative to antibiotics or, at least, as a supplementary approach to treatment of some bacterial infections. Here, we describe the results of bacteriophage application in clinical practice for the treatment of localized infections in wounds, burns, and trophic ulcers, including diabetic foot ulcers. This mini-review

OPEN ACCESS

Edited by:

Sanna Sillankorva,

University of Minho, Portugal

Reviewed by:

Elizabeth Martin Kutter,

The Evergreen State College,

United States

Nina Chanishvili,

George Eliava Institute of Bacteriophage, Microbiology and

Virology, Georgia

Sarah J. Kuhl,

VA Northern California Health Care

System, United States

*Correspondence:

Vera V. Morozova

vera_morozova@ngs.ru

Specialty section:

This article was submitted to Antimicrobials, Resistance and

Chemotherapy,

a section of the journal

Frontiers in Microbiology

Received: 26 April 2018

Accepted: 09 July 2018

Published: 02 August 2018

Citation:

Morozova W, Vlassov W and Tikunova NV (2018) Applications of Bacteriophages in the Treatment of

Localized Infections in Humans.

Front. Microbiol. 9:1696.

doi: 10.3389/fmicb.2018.01696 includes data from various studies available in English, as well as serial case reports published in Russian scientific literature (with, at least, abstracts accessible in English). Since, it would be impossible to describe all historical Russian publications; we focused on publications included clear data on dosage and rout of phage administration.

Keywords: phage therapy, clinical practice, wounds, burns, trophic ulcers, diabetic foot ulcers, therapeutic bacteriophage

\section{INTRODUCTION}

Since their discovery, bacteriophages have been considered to be potential antibacterial therapeutics for the treatment of various infectious diseases in humans. Initially, clinical application of bacteriophages was aimed at the treatment of acute intestinal diseases (Summers, 1999) and skin infections (Bruynoghe and Maisin, 1921). Later, bacteriophages were applied in surgical practice for treatment of purulent wounds and postoperative infectious complications, and this approach was used in the USSR in the thirties and forties of the twentieth century (Tsulukidze, 1940; Kokin, 1941; Krestovnikova, 1947). After the advent of antibiotics, phage therapy was ceased in most countries and considerably decreased in surgical practice in the USSR. However, the use of bacteriophages in the clinical treatment of infected wounds was not stopped in Eastern Europe and the former $\mathrm{SU}$, as antibiotic treatment of such infections sometimes failed, even in cases of antibiotic-sensitive bacteria. Phage preparations approved for clinical application have been produced in the Russian Federation, Republic of Georgia, and Poland, and a large number of studies on phage therapy have been reported in these countries (Weber-Dabrowska et al., 2000; Sulakvelidze et al., 2001; Chanishvili, 2009, 2016; Górski et al., 2009; Miedzybrodzki et al., 2012; etc), including investigations published in Russian scientific literature (Zhukov-Verezhnikov et al., 1978; Bogovazova et al., 1991; Perepanova et al., 1995; Brusov et al., 2011; etc.).

The rapid rise of multi-drug resistant bacteria worldwide has led to a renewed interest in phage therapy as a possible alternative to antibiotics or, at least, a supplementary approach for the treatment of some bacterial infections. Recently, the results of bacteriophage and phage cocktail application for the treatment of various infections have been reported in a number of clinical cases, case series and clinical trials (Rhoads et al., 2009; Wright et al., 2009; Fish et al., 2016; Jennes et al., 2017). Despite the promising results from phage therapy, still there are no commonly approved 
recommendations or therapeutic schemes for phage application. Development of these schemes is complicated by the diversity of phage preparations used (some of which are not even fully characterized), the variety of routes of administration and courses of phage treatment. Notably, the various localizations of bacterial infections require identification of the most preferable routes and therapeutic schemes of phage administration. In this mini-review, we focus on the results of phage therapy applied in the clinical treatment of localized infections in wounds, burns, and trophic ulcers, including diabetic foot ulcers.

\section{BACTERIOPHAGE TREATMENT OF WOUND INFECTIONS AND INFECTIOUS COMPLICATIONS OF SURGICAL WOUNDS}

D'Herelle's enthusiasm concerning the wide possibilities of phage therapy led to extensive attempts to isolate bacteriophages that were active against bacterial agents found in infected wounds and apply them in treatment. As a result, phage therapy was used in the USSR during the Finnish Campaign (19391940) and continued during the World War II (Tsulukidze, 1940, 1941; Kokin, 1941, 1946; Pokrovskaya et al., 1941; Krestovnikova, 1947). The majority of this historical data (except the study published by Pokrovskaya et al., 1941) was described in a previously published review (Chanishvili, 2012). It was reported that the mixtures of bacteriophages active against Clostridium perfringens, Staphylococcus spp., and Streptococcus spp. were used for the prevention and treatment of gas gangrene (Kokin, 1941). Several studies demonstrated high effectiveness of phage application in an early stage of infection (Kokin, 1941; Pokrovskaya et al., 1941; Tsulukidze, 1941). To improve the efficacy of phage therapy, "Pyophage" (a poly-specific cocktail of phages) was applied initially, and after detection of the etiologic agents, mono-specific lytic phages were used (Pokrovskaya et al., 1941; Tsulukidze, 1941; Krestovnikova, 1947). The best results were achieved in the treatment of Staphylococcal and Streptococcal infections, and phage application led to the elimination of 69 and 50\% of these bacterial pathogens, respectively (Pokrovskaya et al., 1941). A course of phage treatment included washings of a wound with a phage preparation and subcutaneous injections of phages from one to four times per day. Five to eight days of therapy were sufficient for clinical improvement in the majority of cases; however, if no improvement was achieved during this period, further phage application was useless (Pokrovskaya et al., 1941; Table 1).

Despite the widespread introduction of antibiotics, phage preparations continued to be used in the USSR and, later, in the Russian Federation for the prevention of wound infections and treatment of infectious complications of surgical wounds (Table 1). Poly-specific (Pyophage, Sekstaphage) and mono-specific therapeutic phage cocktails developed in research institutes and pharmaceutical companies were used in the USSR. In the recent years, phage preparations produced in JSC Microgen (http://www.bacteriofag.ru) have been applied. Bacteriophages were administered locally, by subcutaneous injections, and orally (Table 1). Notably, phage therapy was carried out as a mono-therapy (Zhukov-Verezhnikov et al., 1978; Peremitina et al., 1981; Kochetkova et al., 1989; Brusov et al., 2011), or in complex treatments, which included phages and antibiotics administration (Kochetkova et al., 1989; Khairullin et al., 2002). The investigations revealed that complex treatments decreased the healing time by 1.2-2.5 times compared to an antibiotic treatment (Kochetkova et al., 1989; Khairullin et al., 2002; Table 1). Even application of bacteriophages specific to one of the infectious agents in a wound improved healing and stimulated faster purification (Ponomareva et al., 1985; Khairullin et al., 2002). This positive effect was, probably, due to the partial destruction of biofilms, influence of bacteriophages on the regenerative processes in a wound and on the immune system of a patient (Miedzybrodzki et al., 2009; Górski et al., 2017; Van Belleghem et al., 2017). Importantly, it has been shown that a single application of a bacteriophage could not be enough to prevent infectious complications of wounds (Brusov et al., 2011; Table 1).

Phage therapy was applied for the treatment of infected post-operative wounds in cancer patients (Ponomareva et al., 1985; Kochetkova et al., 1989). It resulted in faster cleaning of wounds from purulent masses, granulation, and healing without deforming scars compared to a group of cancer patients which were treated with antibiotics (Table 1). In one of these studies, the fastest wound healing was observed in patients treated only by bacteriophages (Kochetkova et al., 1989; Table 1). However, it would not be correct to conclude that application of bacteriophages without antibiotics is preferable, as investigators have used complex treatments in patients with more severe infections, previously unsuccessfully treated with antibiotics. Based on the obtained data, the authors have suggested that application of phage preparations provided positive effect in mono-infection, while complex therapy, including bacteriophages and antibiotics, was required in mixed bacterial infection (Kochetkova et al., 1989). One of the reasons for using complex treatments may be the inability of quick selection of lytic bacteriophages active against all pathogens in a wound.

Another important issue of phage therapy is the question of which is better to use: one specific bacteriophage or a poly-specific phage cocktail. Application of highly specific bacteriophages (adapted by cultivation on a bacterial strain isolated from a patient) was more effective than treatment with poly-specific phage cocktails (Zhukov-Verezhnikov et al., 1978; Table 1). The significantly higher efficiency of this type of personalized phage therapy can be explained by the improvement of the specificity and virulence of phages to host strains. However, the adapted phage preparations require detailed characterization because they may contain temperate bacteriophages produced by the clinical bacterial strain, which was used for adaptation.

\section{PHAGE TREATMENT OF INFECTED BURNS}

Burn surfaces are rapidly colonized by bacteria, which are capable of producing biofilms and are often resistant to multiple 


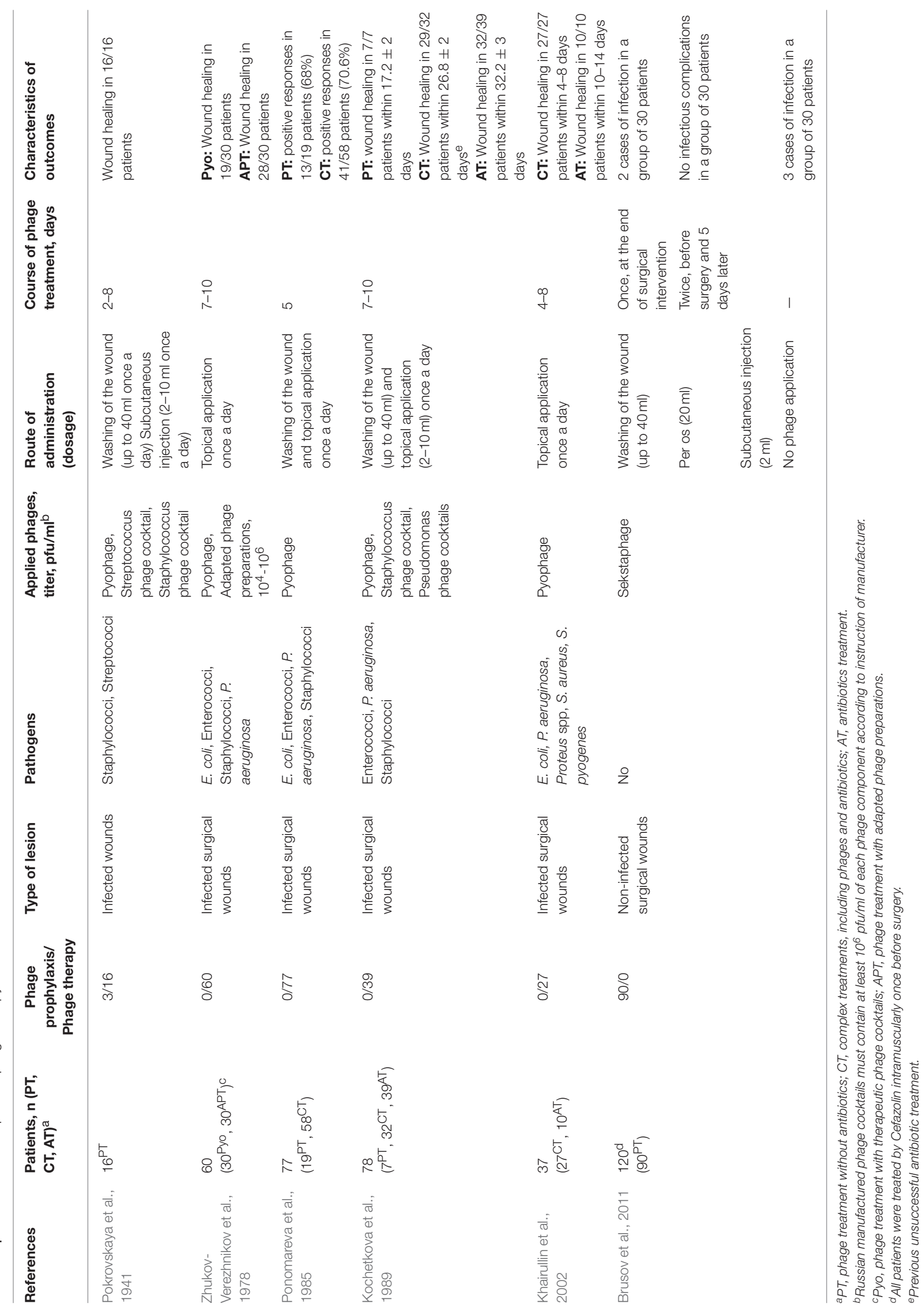


antibiotics (Erol et al., 2004; Church et al., 2006; Asati and Chaudhary, 2017). Additionally, patients with burns frequently suffer from lymphopenia, sepsis, intoxication, and changes in the microbiota (Erol et al., 2004). Phage therapy could potentially be used to treat burns and prevent sepsis. Several case series have been reported (Gomareli et al., 1976; Abul-Hassan et al., 1990; Lazareva et al., 2001; Sivera Marza et al., 2006; Rose et al., 2014), and promising results have been demonstrated in some reports (Table 2). Topical application of phages led to the elimination of multiple drug resistant (MDR) P. aeruginosa or successful skin graft take in 18 of 30 patients with burns, but the method was time-consuming, and the authors recommended this therapy only for infections resistant to available antibiotics (AbulHassan et al., 1990). In other investigation, it was revealed that bacteriophage application in complex therapy (bacteriophages per os and antibiotics) provided better clinical dynamics in patients with infected burns compared to a group of antibiotictreated patients (Lazareva et al., 2001; Table 2). Notably, the first group included a higher number (29\%) of initially complicated cases (intoxication, sepsis, purulent discharge of wounds), in contrast to $12.6 \%$ of such cases in the antibiotic-treated group (Lazareva et al., 2001).

The dosage of phage preparation is believed to be very important in phage therapy, and the therapeutic titer should be higher than $10^{6} \mathrm{pfu} / \mathrm{ml}$. Much more concentrated phage suspensions are applied in the majority of reported cases (Table 2). However, phage BS24 (Soothill, 1994), which was used at a low titer $\left(10^{3} \mathrm{pfu} / \mathrm{ml}\right.$, single application), provided a positive effect (Sivera Marza et al., 2006). In another investigation (Rose et al., 2014), no positive response was recorded when the phage cocktail BFC-1 (Merabishvili et al., 2009) was applied at a high titer $\left(10^{9} \mathrm{pfu} / \mathrm{ml}\right.$, single application). The investigators explained this insufficient result by several possible reasons, such as a delay in phage application, previously initiated systemic and topical antimicrobial treatment, and unsuitable pharmaceutical form of BFC-1 (Rose et al., 2014). It is possible that the result of phage therapy depends on both phage titer and a number of other reasons, including sensitivity and accessibility of bacterial host to the phage, routes of phage administration, duration of phage treatment course, and so on.

Recently, a phase I/II clinical trial was dedicated to the study of safety, effectiveness, and pharmacodynamics of two phage cocktails to treat $E$. coli, and $P$. aeruginosa burn wound infections (http://www.phagoburn.eu). The results of this study, which was conducted for 3 years in France, Switzerland, and Belgium, may help the development of dose and treatment scheme recommendations for phage therapy of infected burns.

\section{PHAGE THERAPY OF PATIENTS WITH INFECTED ULCERS}

Chronic trophic ulcers occur as a complication of some disorders, such as chronic insufficiency of blood circulation (atherosclerosis, varicosity), diabetes, peripheral polyneuropathy of the limbs, and so on. It is believed that the rate of healing of ulcers depends on the concurrent infection; meanwhile, the spectrum of aerobic and anaerobic microorganisms inhabiting chronic wounds is very diverse (Rhoads et al., 2012; Wolcott et al., 2016). Microbiomes of chronic ulcers and, particularly, of diabetic foot ulcers (DFU) are associated with clinical factors: superficial ulcers and those with a shorter duration are usually infected with Staphylococcus spp., mainly S. aureus, in a relatively high titer; deep ulcers and those with a longer duration are colonized with the diverse microbiota that contains Proteobacteria and anaerobes, including Anaerococcus, Peptonihilus, Bacteroides, and Clostridium genera (Gardner et al., 2013; Spichler et al., 2015). According to $16 \mathrm{~S}$ rDNA pyrosequence analyses of microbiomes from $\sim 3,000$ ulcers, only one infectious agent was found in $7 \%$ of infected ulcers (Wolcott et al., 2016). S. aureus and $P$. aeruginosa were found to be predominant and the most pathogenic species commonly persisting in chronic wounds (Wolcott et al., 2016), and their elimination would lead to improvement and wound healing in the majority of cases. However, antibacterial treatment of ulcers infected with diverse microbial agents is usually complicated, primarily by microbial biofilm formation and high level of antibiotic resistance (Malik et al., 2013; Rahim et al., 2016; Di Domenico et al, 2017). Long-term administration of antibiotics is sometimes ineffective; especially in diabetes mellitus patients, long-term administration of antibiotics is often unsafe, because they may suffer from diabetic nephropathy and hepatic insufficiency.

Phage therapy could be an alternative to antibiotics or, at least, a supplementary approach to the treatment of infected ulcers. Currently, several studies (Table 2) have reported the efficiency and safety of phage treatment of infected trophic ulcers in humans (Markoishvili et al., 2002; Rhoads et al., 2009; Fish et al., 2016, 2018; Vlassov et al., 2016; Morozova et al., 2018). A large case series (96 patients) demonstrated a positive effect of PhagoBioDerm (a biodegradable wound dressing impregnated with the phage cocktail Pyophage) on the healing of venous leg ulcers (Markoishvili et al., 2002; Table 2). These biodegradable polymers contain different antimicrobial substances and are of particular interest because of their ability to degrade slowly and release active antimicrobials, including phage particles, for a long time. The use of PhagoBioDerm reduced the number of treatments and hence, injuring of wounds; therefore, this type of material is promising for both therapy and prevention of microbial infections in wounds (Markoishvili et al., 2002; Jikia et al., 2005).

Later, a phase I safety trial of a cocktail of bacteriophages WPP-201 was performed (Rhoads et al., 2009). WPP-201 was applied topically to venous leg ulcers, and its safety was confirmed as it did not lead to an increase in the number of side effects compared to the standard therapy. Meanwhile, the rate of wound healing was the same in both the experimental and control groups (Rhoads et al., 2009). Since the aim of the trial was to demonstrate the safety of the phage cocktail rather than its effectiveness, the study did not provide information on the composition and number of infectious microorganisms, which might not be sensitive to phages from the WPP-201 cocktail. 


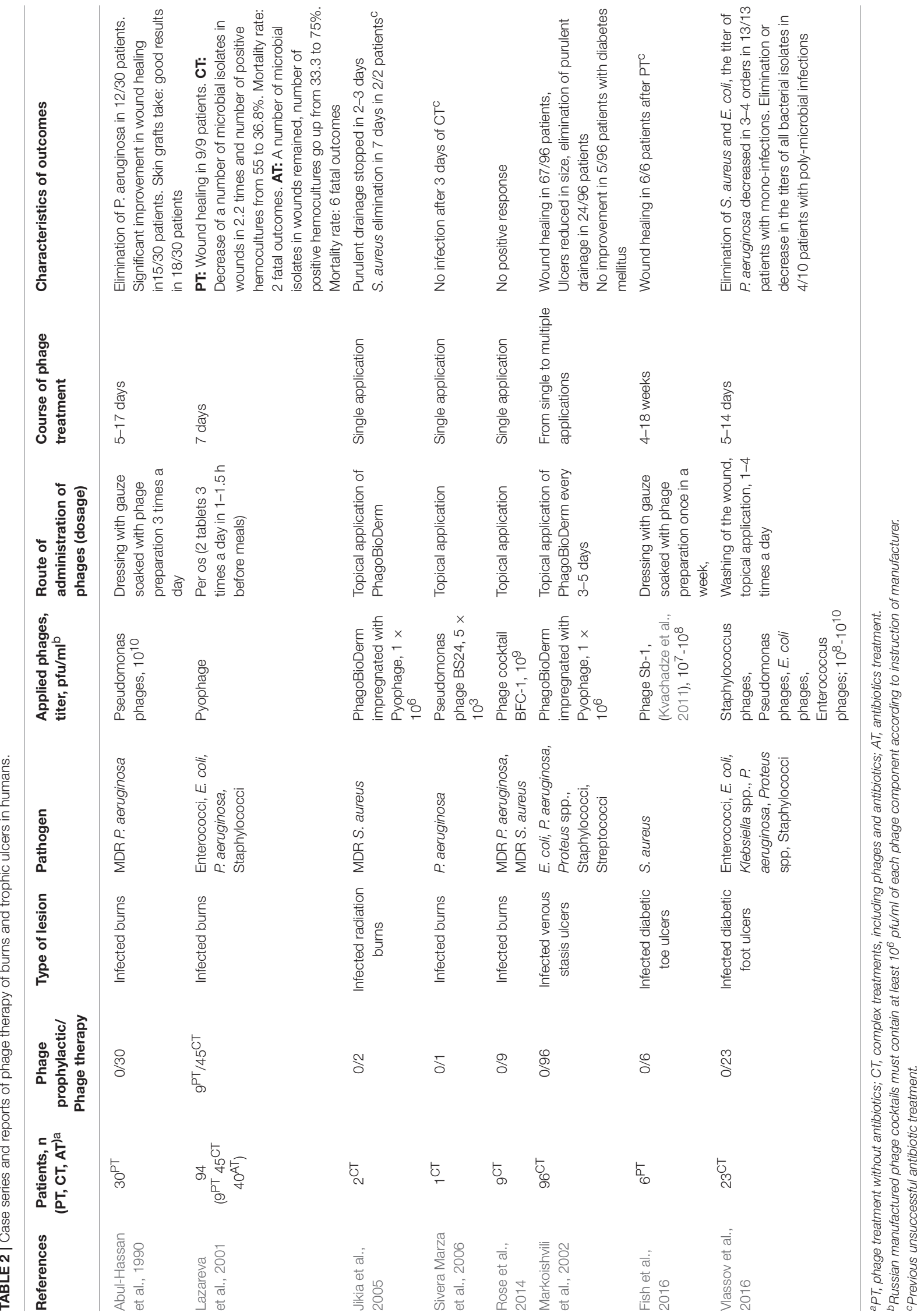


The use of bacteriophages that were specific to infectious agents demonstrated clear positive results (Table 2). Staphylococcus phage Sb-1 (Kvachadze et al., 2011) was successfully used in the treatment of patients with DFU infected with methicillin-resistant and methicillin-sensitive $S$. aureus strains, as it has been described in a case series report (Fish et al., 2016). Phage therapy without antibiotics resulted in subsequent wound healing in all treated patients (Fish et al., 2016, 2018; Table 2). Another investigation reported phage treatment of patients with various infections of DFU, in whom previous antibiotic treatment was not successful (Vlassov et al., 2016; Morozova et al., 2018; Table 2). Importantly, commercially available phage cocktails were selected in each case individually according to their specificity to particular infectious agents in an ulcer. When no specific phage cocktail was found, a custom-made phage preparation was prepared. Phage treatment was most effective in ulcers with one bacterial agent (100\%), but a personalized approach led to the elimination of pathogens, even in several cases with mixed infections. The main difficulty in treating of wounds infected with several pathogenic bacteria was the inability to quickly select phages against all identified bacterial agents (Vlassov et al., 2016; Morozova et al., 2018; Table 2).

\section{CONCLUSION}

Extensive empirical experience of phage therapy of localized infections has been accumulated over 100 years of bacteriophage application in treatment of infectious diseases (Weber-Dabrowska et al., 2000; Sulakvelidze et al., 2001; Miedzybrodzki et al., 2012; Chanishvili, 2016; Górski et al., 2017), and the safety of bacteriophages for use in humans has been repeatedly demonstrated (Bruttin and Brüssow, 2005; Rhoads et al., 2009; Wright et al., 2009; Rose et al., 2014). Different schemes and routes of phage administration have been applied, varying from single oral or intravenous applications to multiple topical treatments per day for 12-15 weeks (Arsentieva, 1941; Meladze et al., 1982; Weber-Dabrowska et al., 2000; Brusov et al., 2011; Miedzybrodzki et al., 2012; Fish et al., 2016; Jennes et al., 2017; Chan et al., 2018; etc). Analysis of reported results of phage therapy of localized infections allowed us to draw several conclusions.

Phage application was more effective in an early stage of acute wound infection and 5-10 days of phage therapy provided positive clinical results in the majority of cases (Kokin, 1941; Pokrovskaya et al., 1941; Tsulukidze, 1941). The results of phage treatment depended on the pathogen species, and the best results were achieved in the treatment of infections caused by Staphylococcus spp. and Streptococcus spp. (Kokin, 1941; Pokrovskaya et al., 1941; Miedzybrodzki et al., 2012).

In the treatment of infected chronic ulcers, mostly longterm application of phage preparations (up to several weeks) provided positive clinical effect (Weber-Dabrowska et al., 2000; Markoishvili et al., 2002; Miedzybrodzki et al., 2012; Fish et al., 2016). Importantly, multiple changes of dominant pathogens may occur in infected chronic ulcers during phage treatment (Morozova et al., 2018). This situation requires timely replacement of ineffective bacteriophages. Therefore, large collections of therapeutic phage preparations would be useful, because diverse bacterial communities have been recorded in most chronic wounds and ulcers. Even when only part of the infectious agents are susceptible to therapeutic phages, phage therapy might be a reasonable supplementary approach providing the elimination of dominant pathogens. Moreover, different bacteria in the ulcer's microbiota may be resistant to various antibiotics, leading to the inability to choose one appropriate antibiotic for therapy. So, complex treatments, including antibiotics and bacteriophages, may be the optimal solution in this case.

It is possible that phage therapy should be personalized, which means individual selection and custom-made phage preparation, and in some cases, an adaptation of bacteriophage to infectious agent isolated from a patient (Zhukov-Verezhnikov et al., 1978; Pirnay et al., 2011, 2018; Schooley et al., 2017; Rohde et al., 2018). Poly-specific cocktails of bacteriophages might be applied preventively or at the beginning of treatment before identification of etiologic agents.

Phages were applied topically in the majority of studies (Tables 1, 2); though the early Soviet investigations reported subcutaneous, intramuscular, and intravenous administration of phages in successful treatment of wound infection (Arsentieva, 1941; Kokin, 1941; Krestovnikova, 1947, etc). It should be noted, that Staphylococcus phage developed by the Eliava Institute of Bacteriophage (Tbilisi, Republic of Georgia) was successfully applied intravenously for treatment of infections in children and adults in the late soviet times (Meladze et al., 1982; Samsygina and Boni, 1984). A range of doses of phage preparations provided positive results, presumably reflecting their ability to replicate where the target pathogen is present. Further accumulation of data in the field of phage therapy of localized infections should help to develop optimal dosage and routes of administration of phage preparation.

\section{AUTHOR CONTRIBUTIONS}

All co-authors have made equal contribution to the writing and editing of the article. All authors read and approved the final version of the manuscript.

\section{FUNDING}

This study was supported by the Program of Fundamental Scientific Research of Russian Academy of Sciences Project ST No 0309-2018-0011, and Russian Federal Agency for Science and Innovation project VI.55.1.1, No 0309-201 6-0002. 


\section{REFERENCES}

Abul-Hassan, H. S., El-Tahan, K., Massoud, B., and Gomaa, R. (1990). Bacteriophage therapy of Pseudomonas burn wound sepsis. Ann. Mediterr. Burn Club 3, 262-264.

Arsentieva, A. V. (1941). Intravenous use of high doses of bacteriophages in surgery. Sov Med. 9, 18-20. [Article in Russian].

Asati, S., and Chaudhary, U. (2017). Prevalence of biofilm producing aerobic bacterial isolates in burn wound infections at a tertiary care hospital in northern India. Ann. Burns Fire Disasters 30, 39-42.

Bogovazova, G. G., Voroshilova, N. N., and Bondarenko, V. M. (1991). The efficacy of Klebsiella pneumoniae bacteriophage in the therapy of experimental Klebsiella infection. Zh. Mikrobiol. Epidemiol. Immunobiol. 4, 5-8. [Article in Russian].

Brusov, P. G., Zubritsky, V. F., Nizovoy, A. V., and Fominykh, E. M. (2011). Phagoprophylaxis and bacteriophage treatment of surgical infections. Mil. Med. J. 4, 34-39. [Article in Russian].

Bruttin, A., and Brüssow, H. (2005). Human volunteers receiving Escherichia coli phage T4 orally: a safety test of phage therapy. Antimicrob. Agents Chemother. 49, 2874-2878. doi: 10.1128/AAC.49.7.2874-2878.2005

Bruynoghe, R., and Maisin, J. (1921). Essais de the'rapeutique au moyen du bacteriophage. C. R. Soc. Biol. 85, 1120-1121.

Chan, B. K., Turner, P. E., Kim, S., Mojibian, H. R., Elefteriades, J. A., and Narayan, D. (2018). Phage treatment of an aortic graft infected with Pseudomonas aeruginosa. Evol Med Public Health. 2018. 60-66. doi: 10.1093/emph/eoy005

Chanishvili, N. (2009). A Literature Review of the Practical Application of Bacteriophage Research. New York, NY: Nova Science Publishers.

Chanishvili, N. (2012). Phage therapy-history from twort and d'herelle through soviet experience to current approaches. Adv. Virus Res. 83, 4-40. doi: 10.1016/B978-0-12-394438-2.00001-3

Chanishvili, N. (2016). Bacteriophages as therapeutic and prophylactic means: summary of the Soviet and Post-Soviet Experiences. Curr. Drug Deliv. 13, 309-323. doi: 10.2174/156720181303160520193946

Church, D., Elsayed, S., Reid, O., Winston, B., and Lindsay, R. (2006). Burn wound infections. Clin. Microbiol. Rev. 19, 403-434. doi: 10.1128/CMR.19.2.403-434.2006

Di Domenico, E. G., Farulla, I., Prignano, G., Gallo, M. T., Vespaziani, M., Cavallo, I., et al.(2017). Biofilm is a major virulence determinant in bacterial colonization of chronic skin ulcers independently from the multidrug resistant phenotype. Int. J. Mol. Sci. 18:E1077. doi: 10.3390/ijms18051077

Erol, S., Altoparlak, U., Akcay, M. N., Celebi, F., and Parlak, M. (2004). Changes of microbial flora and wound colonization in burned patients. Burns 4, 357-361. doi: 10.1016/j.burns.2003.12.013

Fish, R., Kutter, E., Wheat, G., Blasdel, B., Kutateladze, M., and Kuhl, S. (2016). Bacteriophage treatment of intransigent diabetic toe ulcers: a case series. J. Wound Care 25, S27-S33. doi: 10.12968/jowc.2016.25.7.S27

Fish, R., Kutter, E., Wheat, G., Blasdel, B., Kutateladze, M., and Kuhl, S. (2018). Compassionate use of bacteriophage therapy for foot ulcer treatment as an effective step for moving towards clinical trials. Methods Mol. Biol. 1693, 159-170. doi: 10.1007/978-1-4939-7395-8_14

Gardner, S. E., Hillis, S. L., Heilmann, K., Segre, J. A., and Grice, E. A. (2013). The neuropathic diabetic foot ulcer microbiome is associated with clinical factors. Diabetes 62, 923-930. doi: 10.2337/db12-0771

Gomareli, G. G., Iasvili, B. P., Chanisvvili, T. G., Sharashidze, T. G., and Katsitadze, G. L. (1976). Experience of using bacteriophages passaged on auto cultures in the treatment of burn wounds. Proc. Res. Inst. Emerg. Care. 25, 96-98.

Górski, A., Dabrowska, K., Miedzybrodzki, R., Weber-Dabrowska, B., Łusiak-Szelachowska, M., Jonczyk-Matysiak, E., et al. (2017). Phages and immunomodulation. Future Microbiol. 12, 905-914. doi: $10.2217 /$ fmb-2017-0049

Górski, A., Miedzybrodzki, R., Borysowski, J., Weber-Dabrowska, B., Lobocka, M., Fortuna, W., et al. (2009). Bacteriophage therapy for the treatment of infections. Curr Opin Investig Drugs. 10, 766-774.

Jennes, S., Merabishvili, M., Soentjens, P., Pang, K. W., Rose, T., Keersebilck, E., et al. (2017). Use of bacteriophages in the treatment of colistin-only-sensitive Pseudomonas aeruginosa septicaemia in a patient with acute kidney injury-a case report. Crit. Care 21:129. doi: 10.1186/s13054-017-1709-y
Jikia, D., Chkhaidze, N., Imedashvili, E., Mgaloblishvili, I., Tsitlanadze, G., Katsarava, R., et al. (2005). The use of a novel biodegradable preparation capable of the sustained release of bacteriophages and ciprofloxacin, in the complex treatment of multidrug-resistant Staphylococcus aureus-infected local radiation injuries caused by exposure to Sr90. Clin. Exp. Dermatol. 30, 23-26. doi: 10.1111/j.1365-2230.2004.01600.x

Khairullin, I. N., Pozdeev, O. K., and Shaimordanov, R. (2002). Efficiency of using specific bacteriophages in the treatment and prophylaxis of surgical postoperative infections. Kazan Med. J. 83, 258-261. [Article in Russian].

Kochetkova, V. A., Mamontov, A. S., Moskovtseva, R. L., Erastova, E. I., Trofimov, E. I., Popov, M. I., et al. (1989). Phagotherapy of postoperative suppurativeinflammatory complications in patients with neoplasms. Sov. Med. 6, 23-26. [Article in Russian].

Kokin, G. A. (1941). Use of bacteriophages in surgery. Sov. Med. 9, 15-18. [Article in Russian].

Kokin, G. A. (1946). "Phage therapy and phage prophylaxis of gas gangrene," in The Experience of the Soviet Military Medicine during the Great Patriotic War 1941-1945, (Moscow: Medgiz), Vol. 3, 56-63.

Krestovnikova, V. A. (1947). Phage treatment and phage prophylactics and their approval in the works of the Soviet researchers. J. Microb. Epidemiol. Immunol. 3, 56-65. [Article in Russian].

Kvachadze, L., Balarjishvili, N., Meskhi, T., Tevdoradze, E., Skhirtladze, N., and Pataridze, T. (2011). Evaluation of lytic activity of staphylococcal bacteriophage Sb-1 against freshly isolated clinical pathogens. Microb. Biotechnol. 4, 643-650. doi: 10.1111/j.1751-7915.2011.00259.x

Lazareva, E. B., Smirnov, S. V., Khvatov, V. B., Spiridonova, T. G., Bitkova, E. E., Darbeeva, O. S., et al. (2001). Efficacy of bacteriophages in complex treatment of patients with burn wounds. Antibiot. Khimioter. 46, 10-14. [Article in Russian].

Malik, A., Mohammad, Z., and Ahmad, J. (2013). The diabetic foot infections: biofilms and antimicrobial resistance. Diabetes Metab. Syndr. 7, 101-107. doi: 10.1016/j.dsx.2013.02.006

Markoishvili, K., Tsitlanadze, G., Katsarava, R., Morris, J. G., and Sulakvelidze, A. (2002). A novel sustained-release matrix based on biodegradable poly(ester amide)s and impregnated with bacteriophages and an antibiotic shows promise in management of infected venous stasis ulcers and other poorly healing wounds. Int. J. Dermatol. 41, 453-458. doi: 10.1046/j.1365-4362.2002.0 1451.x

Meladze, G. D., Mebuke, M. G., Chkhetia, N.,Sh., Kiknadze, N.,Ya., Koguashvili, G. G., Timoshuk, I. I., et al. (1982). The efficacy of staphylococcal bacteriophage in the treatment of purulent diseases of the lungs and pleura. Grudnaya Khirurgiya 24, 53-56. [Article in Russian].

Merabishvili, M., Pirnay, J.-P., and Verbeken, G. (2009). Quality-controlled smallscale production of a well-defined bacteriophage cocktail for use in human clinical trials. PLoS ONE 4:e4944. doi: 10.1371/journal.pone.0004944

Miedzybrodzki, R., Borysowski, J., Weber-Dabrowska, B., Fortuna, W., Letkiewicz, S., Szufnarowski, K., et al. (2012). Clinical aspects of phage therapy. Adv. Virus Res. 83, 73-121. doi: 10.1016/B978-0-12-394438-2.00003-7

Miedzybrodzki, R., Fortuna, W., Weber-Dabrowska, B., and Górski, A. (2009). A retrospective analysis of changes in inflammatory markers in patients treated with bacterial viruses. Clin. Exp. Med. 9, 303-312. doi: 10.1007/s10238-009-0044-2

Morozova, V. V., Kozlova, Y.u., Ganichev, D., and Tikunova, N. (2018). Bacteriophage treatment of infected diabetic foot ulcers. Methods Mol. Biol. 1693, 151-158. doi: 10.1007/978-1-4939-7395-8_13

Peremitina, L. D., Berillo, E. A., and Khvoles, A. G. (1981). Experience in the therapeutic use of bacteriophage preparations in suppurative surgical infections. Z. Mikrobiol. Epidemiol. Immunobiol. 9, 109-110. [Article in Russian].

Perepanova, T. S., Darbeeva, O. S., Kotliarova, G. A., Kondrat'eva, E. M., Maiskaia, L. M., Malysheva, V. F., et al. (1995). The efficacy of bacteriophage preparations in treating inflammatory urologic diseases. Urol. Nefrol. 5, 14-17. [Article in Russian].

Pirnay, J. P., De Vos, D., Verbeken, G., Merabishvili, M., Chanishvili, N., Vaneechoutte, M., et al. (2011). The phage therapy paradigm: prêt-à-porter or sur-mesure? Pharm. Res. 28, 934-937. doi: 10.1007/s11095-010-0313-5

Pirnay, J. P., Verbeken, G., Ceyssens, P. J., Huys, I., De Vos, D., Ameloot, C., et al. (2018). The magistral phage. Viruses. 10:e64. doi: 10.3390/v10020064 
Pokrovskaya, M. P., Kaganova, L. C., Morosenko, M. A., Bulgakova, A. G., and Skatsenko, E. E. (1941). Treatment of Wounds with Bacteriophages. Moscow: Narkomzdrav.

Ponomareva, T. R., Smolianskaia, A. Z., Sokolova, E. N., Sokolova, V. I., and Garnova, N. A. (1985). Bacteriophages in the treatment of postoperative complications in cancer patients. Sov. Med. 4, 89-92. [Article in Russian].

Rahim, K., Qasim, M., Rahman, H., Khan, T. A., Ahmad, I., Khan, N., et al. (2016). Antimicrobial resistance among aerobic biofilm producing bacteria isolated from chronic wounds in the tertiary care hospitals of Peshawar, Pakistan. J. Wound Care 25, 480-486. doi: 10.12968/jowc.2016.25.8.480

Rhoads, D. D., Wolcott, R. D., Kuskowski, M. A., Wolcott, B. M., Ward, L. S., and Sulakvelidze, A. (2009). Bacteriophage therapy of venous leg ulcers in humans: results of a phase I safety trial. J. Wound Care 18, 240-243. doi: 10.12968/jowc.2009.18.6.42801

Rhoads, D. D., Wolcott, R. D., Sun, Y., and Dowd, S. E. (2012). Comparison of culture and molecular identification of bacteria in chronic wounds. Int. J. Mol. Sci. 13, 2535-2550. doi: 10.3390/ijms13032535

Rohde, C., Resch, G., Pirnay, J. P., Blasdel, B. G., Debarbieux, L., Gelman, D., et al. (2018). Expert opinion on three phage therapy related topics: bacterial phage resistance, phage training and prophages in bacterial production strains. Viruses 10: E178. doi: 10.3390/v10040178

Rose, T., Verbeken, G., Vos, D. D., Merabishvili, M., Vaneechoutte, M., and Lavigne, R., et. al. (2014). Experimental phage therapy of burn wound infection: difficult first steps. Int. J. Burns Trauma 4, 66-73.

Samsygina, G. A., and Boni, E. G. (1984). Bacteriophages and phage therapy in pediatric practice. Pediatrics 4, 67-70. [Article in Russian].

Schooley, R. T., Biswas, B., Gill, J. J., Hernandez-Morales, A., Lancaster, J., Lessor, L., et al. (2017). Development and use of personalized bacteriophagebased therapeutic cocktails to treat a patient with a disseminated resistant acinetobacter baumannii infection. Antimicrob. Agents Chemother. 61, e00954e00917. doi: 10.1128/AAC.00954-17

Sivera Marza, J. A., Soothill, J. S., and Boydell, P. (2006). Multiplication of therapeutically administered bacteriophages in Pseudomonas aeruginosa infected patients. Burns 32, 644-646. doi: 10.1016/j.burns.2006.02.012

Soothill, J. S. (1994). Bacteriophage prevents destruction of skin grafts by Pseudomonas aeruginosa. Burns 20, 209-211. doi: 10.1016/0305-4179(94)90184-8

Spichler, A., Hurwitz, B. L., Armstrong, D. G., and Lipsky, B. A. (2015). Microbiology of diabetic foot infections: from Louis Pasteur to 'crime scene investigation'. BMC Med. 13:2. doi: 10.1186/s12916-014-0232-0

Sulakvelidze, A., Alavidze, Z., and Morris, J. G. (2001). Bacteriophage therapy antimicrob agents chemother. 45, 649-659. doi: 10.1128/AAC.45.3.649-659.2001
Summers, W. C. (1999). Felix d'Herelle and the Origins of Molecular Biology. New Haven, CT: Yale University Press.

Tsulukidze, A. P. (1940). Phage treatment in surgery. Surgery ("Khirurgia") 12, 132-133. [Article in Russian].

Tsulukidze, A. P. (1941). Experience of Use of Bacteriophages in the Conditions of War Traumatism. Tbilisi: Gruzmedgiz. [Article in Russian].

Van Belleghem, J. D., Clement, F., Merabishvili, M., Lavigne, R., and Vaneechoutte M. (2017). Pro- and anti-inflammatory responses of peripheral blood mononuclear cells induced by Staphylococcus aureus and Pseudomonas aeruginosa phages. Sci. Rep. 7:8004. doi: 10.1038/s41598-017-08336-9

Vlassov, V. V., Ganichev, D. A., Kozlova, J. N., Morozova, V. V., Saranina, I. V., and Tikunova, N. V. (2016). "Personalised phage therapy of infected trophic ulcers on the background of diabetis," in Abstract Retrieved from Book of Abstracts of 3 rd International Scientific Conference Bacteriophages: Theoretical and Practical Aspects of Their Application in Medicine, Veterinary and Food. Available online at: http://www.congress-phages.ru/_pictures/tezis_bf-2016_block.pdf

Weber-Dabrowska, B., Mulczyk, M., and Górski, A. (2000). Bacteriophage therapy of bacterial infections: an update of our institute's experience. Arch. Immunol. Ther. Exp. 48, 547-551.

Wolcott, R. D., Hanson, J. D., Rees, E. J., Koenig, L. D., Phillips, C. D., Wolcott, R. A., et al. (2016). Analysis of the chronic wound microbiota of 2,963 patients by $16 \mathrm{~S}$ rDNA pyrosequencing. Wound Repair Regen. 24, 163-174. doi: $10.1111 /$ wrr. 12370

Wright, A., Hawkins, C. H., Anggård, E. E., and Harper, D. R. (2009). A controlled clinical trial of a therapeutic bacteriophage preparation in chronic otitis due to antibiotic-resistant Pseudomonas aeruginosa; a preliminary report of efficacy. Clin. Otolaryngol. 34, 349-357. doi: 10.1111/j.1749-4486.2009.01973.x

Zhukov-Verezhnikov, N. N., Peremitina, L. D., Berillo, E. A., Komissarov, V. P., and Bardymov, V. M. (1978). Therapeutic effect of bacteriophage preparations in the complex treatments of suppurative surgical diseases. Sov. Med. 12, 64-66. [Article in Russian].

Conflict of Interest Statement: The authors declare that the research was conducted in the absence of any commercial or financial relationships that could be construed as a potential conflict of interest.

Copyright (c) 2018 Morozova, Vlassov and Tikunova. This is an open-access article distributed under the terms of the Creative Commons Attribution License (CC BY). The use, distribution or reproduction in other forums is permitted, provided the original author(s) and the copyright owner(s) are credited and that the original publication in this journal is cited, in accordance with accepted academic practice. No use, distribution or reproduction is permitted which does not comply with these terms. 